\title{
Identifikasi Karakteristik Fisik Koridor Jalan Tunjungan sebagai Ruang Publik
}

\author{
Ananta Tama Krisetya dan Ardy Maulidy Navastara \\ Departemen Perencanaan Wilayah dan Kota, Fakultas Arsitektur, Desain, dan Perencanaan \\ Institut Teknologi Sepuluh Nopember (ITS) \\ E-mail: ardy.navastara@urplan.its.ac.id
}

\begin{abstract}
Abstrak-Ruang publik merupakan aset utama bagi livability dan perekonomian kota. Jalan merupakan ruang publik yang paling mudah diakses. Jalan tak hanya berfungsi sebagai jalur sirkulasi tetapi juga ruang sosial yang dapat merepresentasikan kehidupan dan identitas kota. Jalan Tunjungan merupakan salah satu jalan yang menjadi identitas Kota Surabaya. Pada perkembangannya, jalan Tunjungan mengalami penurunan intensitas aktivitas dan kegiatan di jalan tersebut. Hal tersebut disebabkan oleh banyaknya bangunan kosong dan tingginya volume lalu lintas di Jalan Tunjungan. Untuk mengatasi masalah tersebut diperlukan adanya konsep pengembangan yang dapat meningkatkan kembali intensitas kegiatan di jalan Tunjungan, salah satunya dengan menjadikan Jalan Tunjungan sebagai ruang publik. Dalam upaya implementasinya, perlu dilakukan studi mengenai karakteristik fisik jalan Tunjungan yang meliputi jenis penggunaan lahan, bentuk bangunan, dan jalur pejalan kaki. Melalui analisis statistik deskriptif, diperoleh hasil identifikasi penggunaan lahan didominasi oleh permukiman dan perdagangan dan jasa, bentuk bangunan dengan frontages yang tidak aktif, serta kondisi jalur pejalan kaki yang belum optimal. Hal ini menunjukan bahwa perlu adanya pengembangan dan peningkatan variabel-variabel tersebut dalam upaya menjadikan jalan Tunjungan sebagai ruang publik.
\end{abstract}

Kata Kunci- Jalan Tunjungan, Ruang Jalan, Ruang Publik.

\section{PENDAHULUAN}

$\mathrm{P}$ ERTUMBUHAN dan pembangunan dalam kota memiliki pengaruh yang luar biasa terhadap hubungan antara masyarakat kota dan ruang perkotaan. Pertumbuhan dan pembangunan suatu kota perlu diiringi dengan penyediaan ruang publik yang memadai yang berfungsi sebagai tempat terjadinya interaksi sosial. Ruang publik suatu kota secara umum dapat berbentuk street dan square[1]. Sementara itu, ruang publik perkotaan yang paling utama adalah jalan dan jalur pedestriannya. Jika ruang jalan sebuah kota terlihat menarik, maka kota tersebut menjadi menarik[2]. Jalan seharusnya menjadi ruang publik dimana terjadi interaksi sosial antar masyarakat dan dapat diakses dengan mudah oleh setiap orang dari segala umur[3].

Koridor jalan Tunjungan yang berada di kawasan CBD Surabaya dan juga merupakan jalan arteri sekunder menyebabkan tingginya lalu lintas kendaraan yang melalui koridor tersebut. Selain itu, koridor jalan Tunjungan hanya dapat memfasilitasi kendaraan pribadi dengan kondisi arus lalu lintas yang hanya satu arah, sehingga menyebabkan bottle-neck effect akibat pertemuan dari tiga jalan raya menjadi satu jalan dan berdampak pada tingginya volume lalu lintas di koridor jalan Tunjungan yang mencapai hingga $4.973 \mathrm{smp} / \mathrm{jam}[4]$. Dengan kondisi tersebut, koridor jalan Tunjungan diklasifikasikan sebagai jalan dengan kondisi lalu lintas sedang[5]. Keadaan volume lalu lintas tersebut menunjukkan bahwa koridor jalan Tunjungan belum ramah pejalan kaki dan menyebabkan berkurangnya kegiatan dan interaksi yang terjadi di jalur pedestrian.

Untuk meningkatkan keselamatan pejalan kaki segala usia, perlu diterapkan tiga aspek, yaitu keamanan, kenyamanan, dan kepuasan[6]. Kondisi jalur pedestrian di koridor jalan Tunjungan belum memenuhi ketiga aspek tersebut. Jalur pedestrian di koridor jalan Tunjungan masih belum aman dan nyaman bagi pejalan kaki. Hal ini disebabkan karena masih ditemukan kendaraan yang parkir ataupun melintas di atas jalur pedestrian tersebut. Selain itu, banyaknya billboard dan tidak adanya jendela display pada pertokoan di koridor jalan Tunjungan menyebabkan kejenuhan bagi para pejalan kaki sehingga mengurangi tingkat kepuasan pejalan kaki[7]. Akibatnya, jalur pedestrian yang ada di koridor ini tidak berfungsi dengan baik dan berpengaruh terhadap aktivitas penggunaan lahan di koridor jalan Tunjungan. Di sepanjang koridor jalan Tunjungan terdapat 59 toko yang tidak difungsikan sehingga menyebabkan koridor ini menjadi terkesan mati.

Tujuan dari penelitian ini adalah untuk mengidentifikasi karakteristik fisik koridor Jalan Tunjungan ditinjau dari fungsi Jalan Tunjungan sebagai ruang terbuka publik. Melalui penelitian ini dapat diketahui karakteristik fisik Jalan Tunjungan yang dapat menjadi pertimbangan pengembangan Jalan Tunjungan oleh Pemerintah Kota Surabaya.

\section{TAHAPAN PENELITIAN}

\section{A. Kajian Pustaka}

Ruang terbuka publik dapat diartikan dalam dua pemahaman, yaitu ruang terbuka publik ditinjau secara fisik dan pengertian ruang terbuka publik ditinjau secara non-fisik. Secara fisik, ruang terbuka publik merupakan ruang atau tempat terbuka yang berada di luar bangunan dan memiliki unsur yang membatasi. Sementara secara non-fisik, ruang terbuka publik ruang atau tempat terjadinya aktivitas dan interaksi sosial yang dapat digunakan secara bebas oleh seluruh orang tanpa terkecuali[8]. Pada umumnya, ruang terbuka publik dapat tergolong menjadi dua jenis, yaitu square (plaza) dan street (jalan). Jalan sebagai salah satu jenis ruang terbuka publik linear, merupakan elemen ruang kota yang dapat mendukung kebutuhan dan dapat digunakan oleh warganya[9]. Fisik jalan diapit oleh elemen fisik sebagai batasnya yang dapat berupa deretan bangunan, PKL, dan deretan pepohonan serta bermacam kegiatan masyarakat yang ada di dalamnya. Jalan sebagai ruang terbuka publik meliputi aspek-aspek sebagai berikut: 1) penggunaan lahan bercampur, 2) pilihan moda transportasi, 3) kenyamanan pejalan kaki, dan 4) memiliki aktivitas sosial yang terjadi di atasnya. Berdasarkan pengertian jalan sebagai ruang terbuka publik dan aspek-aspek yang harus terpenuhi, maka 
penggunaan lahan, bentuk bangunan, dan jalur pejalan kaki dijadikan sebagai variabel penelitian.

\section{B. Jenis dan Pendekatan Penelitian}

Pendekatan yang digunakan dalam penelitian ini adlaah pendekatan Empirical Analytic berdasarkan atas permasalahan dan kondisi yang terjadi pada wilayah penelitian dan Theoritical Analytic menggunakan teori untuk melandasi perumusan variabel-variabel untuk penelitian. Jenis penelitian ini adalah penlitian deskriptif kuantitatif.

\section{Variabel Penelitian}

Variabel penelitian yang digunakan disusun berdasarkan tinjauan literatur terkait dengan jalan sebagai ruang publik, elemen perancangan kota, dan teori livable streets. Variabel yang digunakan untuk mengidentifikasi karakteristik fisik koridor Jalan Tunjungan adalah variabel yang terkait dengan bangunan dan jalur pejalan kaki. Variabel untuk bangunan terdiri dari penggunaan lahan bercampur dan bentuk bangunan, sementara variabel jalur pejalan kaki terdiri dari lebar jalur pejalan kaki, ketersediaan street furniture, dan kondisi jalur pejalan kaki.

Tabel 1.

Variabel Penelitian

\begin{tabular}{|c|c|c|}
\hline Variabel & Sub Variabel & Definisi Operasional \\
\hline $\begin{array}{l}\text { Penggunaan } \\
\text { Lahan } \\
\text { Bercampur }\end{array}$ & - & $\begin{array}{l}\text { Penggunaan aktivitas setiap } \\
\text { bangunan yang beragam }\end{array}$ \\
\hline $\begin{array}{l}\text { Bentuk } \\
\text { bangunan }\end{array}$ & $\begin{array}{l}\text { Active } \\
\text { Frontages }\end{array}$ & $\begin{array}{l}\text { Muka bangunan lantai dasar } \\
\text { yang berbatasan dengan jalur } \\
\text { pejalan kaki yang dapat } \\
\text { ditembus secara visual. }\end{array}$ \\
\hline \multirow{4}{*}{$\begin{array}{l}\text { Kondisi Jalur } \\
\text { Pejalan Kaki }\end{array}$} & $\begin{array}{l}\text { Lebar Jalur } \\
\text { Pejalan Kaki }\end{array}$ & $\begin{array}{l}\text { Bentuk fisik trotoar dan ukuran } \\
\text { lebar trotoar dalam meter. }\end{array}$ \\
\hline & $\begin{array}{l}\text { Ketersediaan } \\
\text { Fasilitas } \\
\text { Penyeberangan }\end{array}$ & $\begin{array}{l}\text { Keberadaan bagian ruang } \\
\text { milik jalan yang diperuntukan } \\
\text { sebagai jalur penghubung dua } \\
\text { trotoar yang terpisah. }\end{array}$ \\
\hline & $\begin{array}{l}\text { Ketersediaan } \\
\text { Peneduh dan } \\
\text { Pelindung }\end{array}$ & $\begin{array}{llr}\text { Keberadaan fasilitas di atas } \\
\text { jalur pejalan kaki } & \text { yang } \\
\text { memberikan fungsi pelindung } \\
\text { dan peneduh. }\end{array}$ \\
\hline & $\begin{array}{l}\text { Ketersediaan } \\
\text { street furniture }\end{array}$ & $\begin{array}{l}\text { Keberadaan perlengkapan jalur } \\
\text { pejalan kaki meliputi lampu } \\
\text { penerangan, tempat duduk, } \\
\text { pagar pengaman, tempat } \\
\text { sampah, halte/shelter dan telpon } \\
\text { umum. }\end{array}$ \\
\hline
\end{tabular}

\section{Metode Pengumpulan Data}

Pengumpulan data dilakukan melalui survey primer untuk mendapatkan data terkait variabel-variabel penelitian. Survei primer dilakukan dengan cara observasi lapangan, dan dokumentasi. Pengumpulan data melalui observasi dilakukan dengan melakukan pembagian wilayah penelitian menjadi beberapa unit amatan. Pembagian unit amatan didasarkan pada jarak pandang dan kesamaan karakteristik bangunan. Berikut merupakan pembagian wilayah unit amatan di wilayah penelitian.

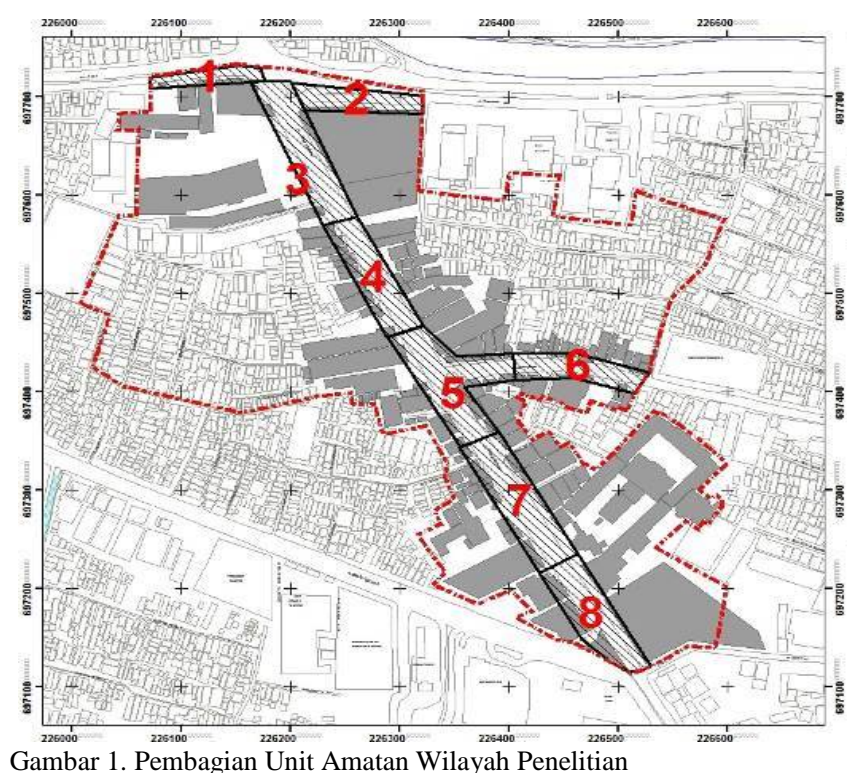

\section{E. Metode Analisis Data}

Analisis data yang diperoleh menggunakan metode statistik deskriptif. Statistik deskriptif adalah statistik yang digunakan dalam menganalisis data dengan cara mendeskripsikan atau menggambarkan data yang telah terkumpul tanpa ada maksud untuk generalisasi. Statistik deskriptif digunakan karena peneliti hanya ingin mendeskripsikan data sampel tanpa menarik kesimpulan. Penyajian data dalam statistik deskriptif dapat berupa tabel, grafik, diagram, perhitungan statistik, atau perhitungan prosentase.

\section{F. Mengidentifikasi Karakteristik Fisik Koridor Jalan Tunjungan}

Dalam mengidentifikasi karakteristik fisik koridor Jalan Tunjungan berdasarkan konsep livable streets digunakan alat analisis statistik deskriptif dengan meninjau variabel-variabel penelitian berupa penggunaan lahan bercampur, bentuk bangunan, dan jalur pejalan kaki. Untuk mengetahui variabel penggunaan lahan didapatkan melalui observasi subvariabel dari variabel penggunaan lahan, yaitu: 1) penggunaan lahan residensial dan 2) penggunaan lahan nonresidensial. Sedangkan untuk variabel bentuk bangunan didapatkan melalui observasi terhadap frontage bangunan yang kemudian diklasifikasikan menjadi frontage aktif dan frontage tidak aktif. Untuk variabel jalur pejalan kaki, didapatkan melalui observasi subvariabel yaitu: 1) ketersediaan jalur pejalan kaki, 2) dimensi jalur pejalan kaki, dan 3) kondisi jalur pejalan kaki. Berdasarkan variabel dan subvariabel tersebut, didapatkan karakteristik fisik koridor Jalan Tunjungan.

\section{HASIL DAN DISKUSI}

\section{A. Identifikasi karakteristik fisik koridor Jalan Tunjungan}

Secara administratif, Koridor Jalan Tunjungan termasuk dalam wilayah Kelurahan Genteng, Kecamatan Genteng, Kota Surabaya. Jalan Tunjungan berfungsi sebagai penghubung antara Kota Surabaya bagian utara dengan pusat Kota Surabaya. Selain itu, Jalan Tunjungan memiliki fungsi jalan arteri sekunder yang menghubungkan pusat-pusat kegiatan dalam skala kota. Ruang lingkup wilayah penelitian ini adalah sepanjang koridor jalan Tunjungan dan kawasan 
sekitarnya. Adapun batas wilayah studi adalah sebagai berikut:

- Utara : Jalan Gemblongan

- Timur : Jalan Genteng Kali dan Jalan Genteng Besar

- Selatan : Jalan Embong Malang dan Jalan Gubernur Suryo

- Barat : Jalan Praban

1) Penggunaan Lahan Bercampur

Penggunaan lahan secara makro di wilayah penelitian meliputi perdagangan dan jasa, fasilitas umum, permukiman, ruang terbuka hijau (RTH), dan bangunan-bangunan kosong yang tidak berfungsi. Adapun penggunaan lahan yang mendominasi adalah permukiman dan perdagangan dan jasa. Untuk mengetahui presentase dari penggunaan lahan residensial dan nonresidensial pada kawasan koridor Jalan Tunjungan, dapat dilihat berdasarkan luas penggunaan lahan masing-masing dibagi dengan luas kawasan. Untuk lebih jelas mengenai presentase penggunaan lahan residensial dan nonresidensial pada kawasan koridor Jalan Tunjungan dapat dilihat pada tabel di bawah ini.

Tabel 2.

Jenis Penggunaan Lahan

\begin{tabular}{llll}
\hline \hline No. & Jenis Penggunaan Lahan & Luas (ha) & Presentase (\%) \\
\hline 1 & Permukiman & 3.829 & 36.34 \\
2 & Perdagangan dan Jasa & 3.217 & 30.53 \\
3 & Fasilitas Umum & 0.239 & 2.27 \\
4 & Perkantoran & 1.380 & 13.10 \\
5 & RTH & 0.8 & 7.59 \\
6 & Campuran & 0.243 & 2.31 \\
7 & Bangunan Kosong & 0.828 & 7.86 \\
& Total & $\mathbf{1 0 . 5 3 6}$ & $\mathbf{1 0 0}$ \\
\hline \hline
\end{tabular}

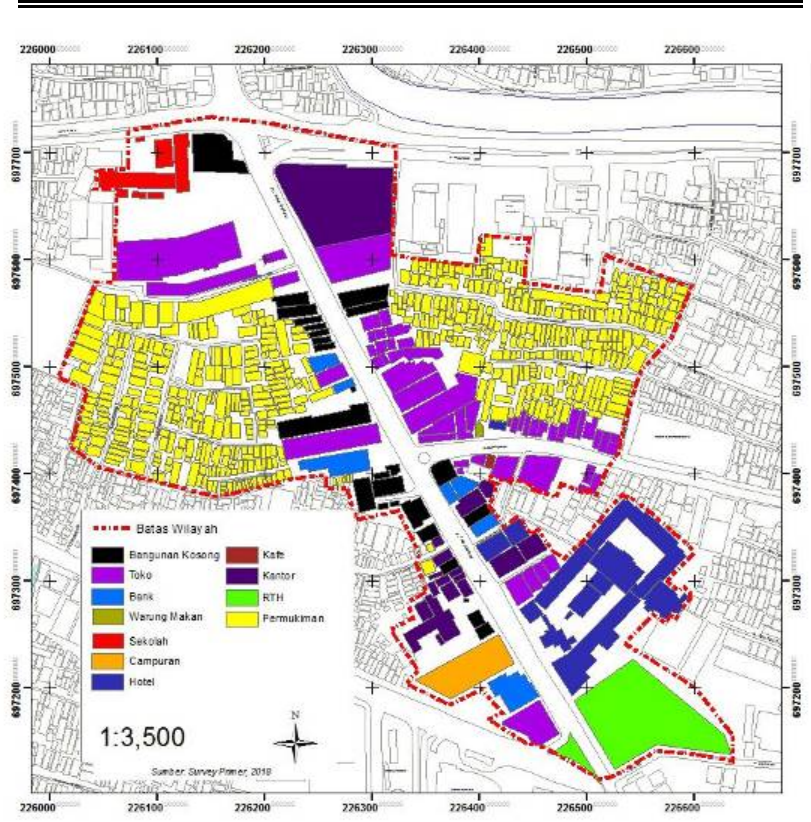

Gambar 2. Hasil identifikasi jenis penggunaan lahan di kawasan koridor jalan Tunjungan

Selain itu, kawasan Koridor Jalan Tunjungan merupakan salah satu kawasan bersejarah di Kota Surabaya yang ditetapkan sebagai kawasan cagar budaya dalam SK Walikota Surabaya No. 188.45/004/402.1.04/1998, sehingga terdapat beberapa bangunan yang juga ditetapkan sebagai bangunan cagar budaya di sepanjang koridor Jalan Tunjungan. Berikut merupakan daftar bangunan cagar budaya yang ada di Jalan Tunjungan.
Tabel 3.

Daftar Bangunan Cagar Budaya

\begin{tabular}{clcc}
\hline \hline No & Bangunan Cagar Budaya & Alamat & Kategori \\
\hline 1 & Kantor BPN & Jl. Tunjungan 80 & A \\
2 & Toko Gading Murni & Jl. Tunjungan 27 & B \\
3 & Bank Hagakita & Jl. Tunjungan 62 & B \\
4 & PT. Gading Murni Solingen & Jl. Tunjungan 37 & B \\
5 & PT. Indah Jaya Elektronik & Jl. Tunjungan 41 & B \\
6 & Komplek Pertokoan & Jl. Tunjungan 55 & B \\
7 & Bank BCA & Jl. Tunjungan 36 & B \\
8 & Toko Lalwani & Jl. Tunjungan 30 & B \\
9 & Monumen Pers & Jl. Tunjungan 100 & D \\
10 & Hotel Majapahit & Jl. Tunjungan 65 & A \\
11 & Bank Dagang Negara & Jl. Tunjungan 39 & B \\
12 & Bank CIMB Niaga & Jl. Tunjungan 47 & B \\
\hline \hline
\end{tabular}

Selain aktivitas bangunan, bangunan cagar budaya merupakan salah satu daya tarik Jalan Tunjungan. Kondisi bangunan cagar budaya dengan fasad bangunan yang masih terjaga menarik masyarakat dan wisatawan untuk datang ke Jalan Tunjungan dan berinteraksi di sana.

\section{2) Bentuk Bangunan}

Bangunan dengan active frontages merupakan salah satu komponen dalam kriteria jalan yang dinamis. Bangunan dengan active frontages selain dapat meningkatkan rasa aman karena adanya pengawasan secara tidak langsung dari dalam bangunan, juga dapat menciptakan aktivitas yang terjadi di lantai dasar bangunan yang berbatasan dengan jalur pejalan kaki sehingga dapat mempengaruhi aktivitas pejalan kaki dalam menggunakan jalan sebagai ruang publik.

Tabel 4.

Klasifikasi Frontage di Koridor Jalan Tunjungan

\begin{tabular}{ccc}
\hline \hline Tipe Frontage & Panjang (m) & Presentase \\
\hline Aktif & 863 & 46.27 \\
Tidak Aktif & 1002 & 53.73 \\
Total & 1865 & 100 \\
\hline \hline
\end{tabular}

Berdasarkan tabel 4, dapat diketahui bahwa muka bangunan yang ada di Jalan Tunjungan masih didominasi oleh muka bangunan yang tidak aktif. Muka bangunan tidak aktif di Jalan Tunjungan dapat diklasifikasikan sebagai berikut: 1) bangunan kosong, 2) bangunan dengan frontage impermeable, 3) bangunan dengan pagar pembatas, dan 4) bangunan yang memiliki setback. 


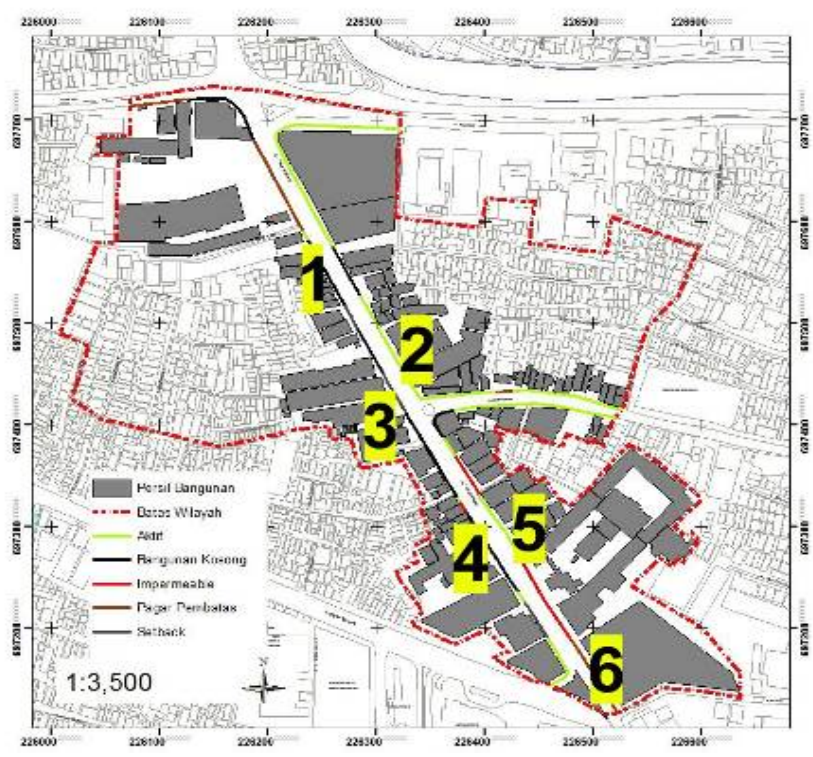

Gambar 3. Klasifikasi frontage tidak aktif di koridor jalan Tunjungan

Frontage bangunan yang tidak aktif menjadi salah satu penyebab menurunnya intensitas kegiatan yang ada di Jalan Tunjungan karena menimbulkan kejenuhan bagi pejalan kaki yang melintas di Jalan Tunjungan. Frontage bangunan yang tidak aktif yang mendominasi di Jalan Tunjungan sebagian besar berupa bangunan kosong. Meski demikian, beberapa bangunan kosong tersebut menjadi salah satu daya tarik karena banyak masyarakat dan wisatawan yang menjadikan kondisi bangunan tersebut sebagai latar untuk berfoto. Hal tersebut dapat mendukung penggunaan Jalan Tunjungan sebagai ruang terbuka publik.

Tabel. 5

Kondisi Eksisting Bentuk Bangunan di Jalan Tunjungan

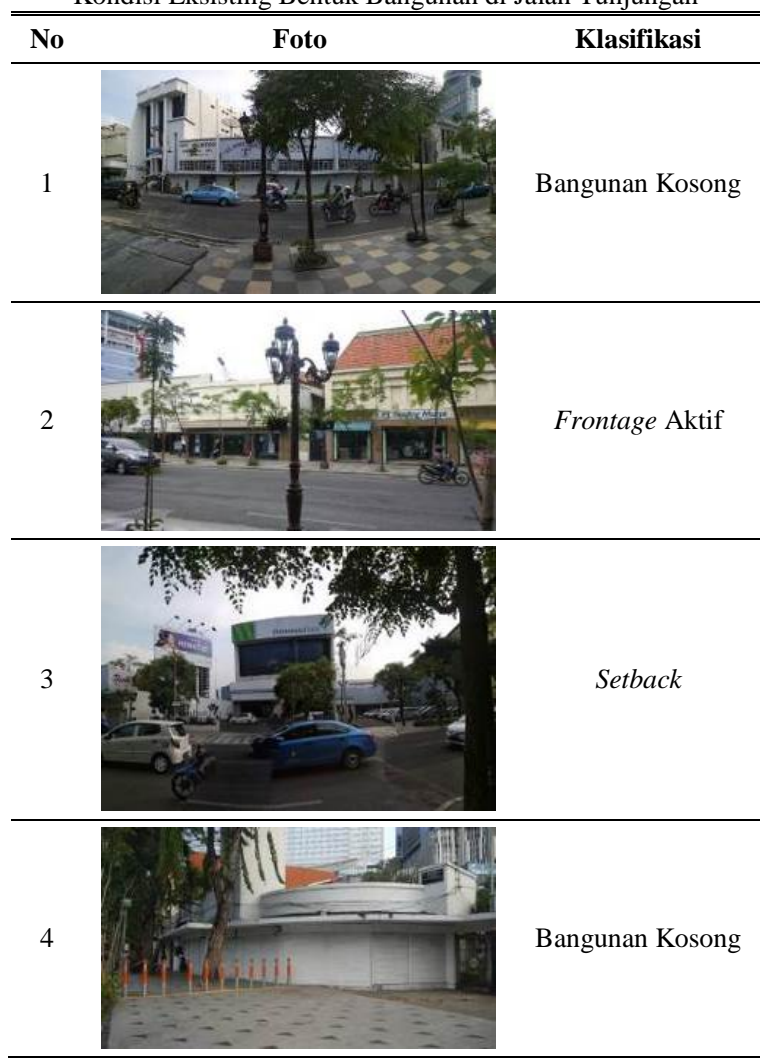

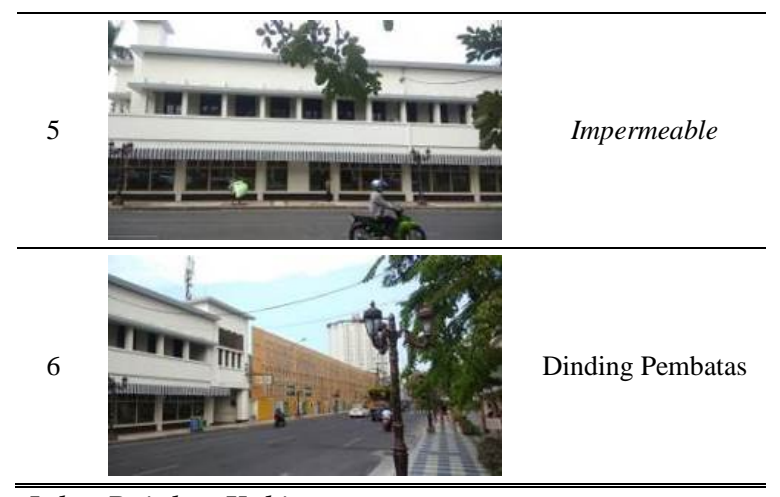

3) Jalur Pejalan Kaki

a. Ketersediaan Jalur Pejalan Kaki

Jalur pejalan kaki tersedia di semua ruas jalan yang ada di kawasan penelitian. Pada Jalan Genteng Besar jalur pejalan kaki sepanjang 122 meter, pada Jalan Praban sepanjang 98 meter, pada Jalan Genteng Kali sepanjang 117 meter, dan pada Jalan Tunjungan sepanjang 1298 meter. Adapun jalur pejalan kaki pada kawasan penelitian terdiri dari dua tipe, yaitu jalur pejalan kaki biasa dan portico. Portico merupakan bagian bangunan terbuka yang menempel bangunan, digunakan untuk area masuk (entrance) bangunan, biasanya memiliki kolom-kolom untuk menyangga atapnya sendiri. Jalur pejalan kaki dengan tipe ini dapat ditemukan pada bangunan-bangunan lama di Jalan Tunjungan.

Tabel 6.

Panjang Jalur Pejalan Kaki di Kawasan Koridor Jalan Tunjungan

\begin{tabular}{lc}
\hline \hline \multicolumn{1}{c}{ Ruas Jalan } & Panjang Jalur Pejalan Kaki (m) \\
\hline Jalan Tunjungan & 1298 \\
Jalan Genteng Besar & 122 \\
Jalan Praban & 98 \\
Jalan Genteng Kali & 117 \\
Total & 1868 \\
\hline
\end{tabular}

Berikut merupakan persebaran tipe jalur pejalan kaki di kawasan penelitian.

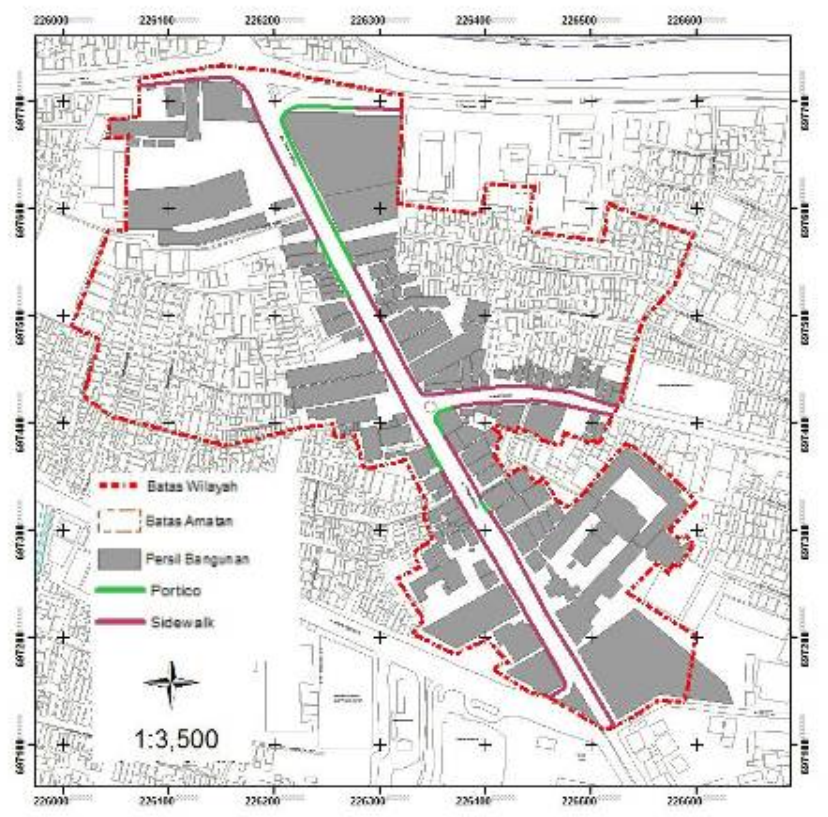

Gambar 4. Klasifikasi jalur pejalan kaki di koridor jalan Tunjungan 

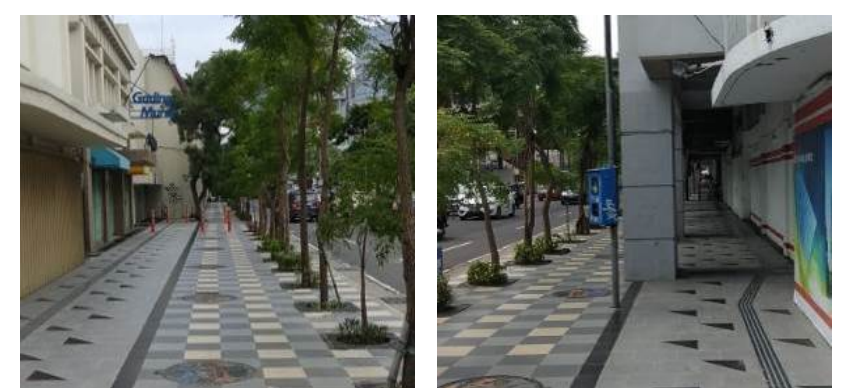

Gambar 5. Tipe jalur pejalan kaki di koridor Jalan Tunjungan berupa sidewalk (kiri) dan portico (kanan)

b. Dimensi Jalur Pejalan Kaki

Kapasitas jalur pejalan kaki memiliki peran yang penting dalam penggunaan jalan sebagai ruang publik. Lebar dari jalur pejalan kaki akan mempengaruhi kebutuhan ruang untuk melakukan aktivitas. Kebutuhan ruang tersebut harus disesuaikan dengan tipe jalan raya serta fungsi kawasan tersebut. Menurut Peraturan Menteri Pekerjaan Umum No. 3 Tahun 2014 tentang Pedoman Perencanaan, Penyediaan, dan Pemanfaatan Prasarana dan Sarana Jaringan Pejalan Kaki di Kawasan Perkotaan, menjelaskan bahwa penyediaan jalur pejalan kaki di kawasan pertokoan/perbelanjaan/hiburan dianjurkan selebar 4 meter. Berdasarkan tabel 6, diketahui bahwa lebar dimensi jalur pejalan kaki di kawasan Jalan Tunjungan masih belum seragam dan belum memenuhi standar yang ada pada unit amatan tertentu. Hal tersebut dapat mempengaruhi penggunaan ruang pejalan kaki.

Tabel 7.

Dimensi Lebar Jalur Pejalan Kaki di Kawasan Koridor Jalan Tunjungan

\begin{tabular}{|c|c|c|c|}
\hline $\begin{array}{c}\text { Unit } \\
\text { Amatan }\end{array}$ & $\begin{array}{c}\text { Lebar } \\
\text { (m) }\end{array}$ & Standard & $\begin{array}{c}\text { Kesesuaian } \\
\text { dengan Standard }\end{array}$ \\
\hline 1 & 3.4 & \multirow{7}{*}{$\begin{array}{l}4 \text { meter (Peraturan } \\
\text { Menteri Pekerjaan } \\
\text { Umum Nomor : } \\
\text { 03/Prt/M/2014 /2011 } \\
\text { Tentang Pedoman } \\
\text { Perencanaan, } \\
\text { Penyediaan, Dan } \\
\text { Pemanfaatan Prasarana } \\
\text { Dan Sarana Jaringan }\end{array}$} & Belum Sesuai \\
\hline 2 & 5.4 & & Sesuai \\
\hline \multirow[t]{3}{*}{3} & 6.7 & & Sesuai \\
\hline & 3.3 & & Belum Sesuai \\
\hline & 4.5 & & Sesuai \\
\hline \multirow[t]{2}{*}{4} & 6.4 & & Sesuai \\
\hline & 6.6 & & Sesuai \\
\hline
\end{tabular}

\begin{tabular}{|c|c|c|c|}
\hline $\begin{array}{c}\text { Unit } \\
\text { Amatan }\end{array}$ & $\begin{array}{l}\text { Lebar } \\
\text { (m) }\end{array}$ & Standard & $\begin{array}{c}\text { Kesesuaian } \\
\text { dengan Standard }\end{array}$ \\
\hline & 5.9 & \multirow{12}{*}{$\begin{array}{c}\text { Pejalan Kaki Di } \\
\text { Kawasan Perkotaan) }\end{array}$} & Sesuai \\
\hline & 4.9 & & Sesuai \\
\hline \multirow[t]{4}{*}{5} & 5.4 & & Sesuai \\
\hline & 3 & & Belum Sesuai \\
\hline & 7.1 & & Sesuai \\
\hline & 6.1 & & Sesuai \\
\hline \multirow[t]{2}{*}{6} & 3 & & Belum Sesuai \\
\hline & 3.4 & & Belum Sesuai \\
\hline \multirow[t]{2}{*}{7} & 4.4 & & Sesuai \\
\hline & 4.5 & & Sesuai \\
\hline \multirow[t]{2}{*}{8} & 3.2 & & Belum Sesuai \\
\hline & 3 & & Belum Sesuai \\
\hline
\end{tabular}
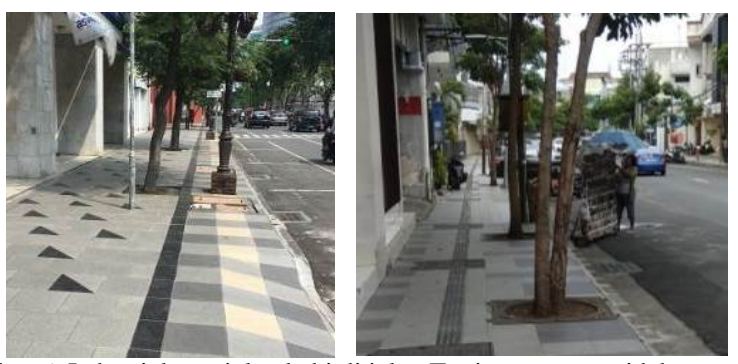

Gambar 6. Lebar jalur pejalan kaki di jalan Tunjungan yang tidak seragam

c. Kondisi Jalur Pejalan Kaki

Berdasarkan Peraturan Menteri Pekerjaan Umum No. 3 Tahun 2014 tentang Pedoman Perencanaan, Penyediaan, dan Pemanfaatan Prasarana dan Sarana Jaringan Pejalan Kaki di Kawasan Perkotaan, penyediaan prasarana jalur pejalan kaki harus memperhatikan beberapa kriteria, yaitu:

1. Kenyamanan, yaitu memiliki fasilitas penunjang dan pelindung dari cuaca.

2. Keamanan, yaitu dapat meminimalisasi tindak kriminal dan mencegah terjadinya kecelakaan dengan kendaraan bermotor.

3. Kemudahan, yaitu dapat diakses oleh seluruh penggunan, termasuk pejalan kaki dengan keterbatasan fisik.

Tabel 8.

Kondisi jalur pejalan kaki di koridor jalan Tunjungan

\begin{tabular}{|c|c|c|c|c|c|}
\hline \multirow{2}{*}{$\begin{array}{l}\text { Unit } \\
\text { Amatan }\end{array}$} & \multicolumn{2}{|c|}{ Kenyamanan } & \multicolumn{2}{|c|}{ Keamanan } & \multirow{2}{*}{$\begin{array}{c}\text { Kemudahan } \\
\text { Guiding block }\end{array}$} \\
\hline & Peneduh dan Pelindung & Street Furniture & Penerangan & Penyeberangan & \\
\hline 1 & Belum tersedia & Sudah tersedia & Tersedia, sudah merata. & Tersedia & Tidak Tersedia \\
\hline 2 & Tersedia & Belum merata. & Tersedia, sudah merata. & Tersedia & Tersedia \\
\hline 3 & $\begin{array}{l}\text { Tersedia, hanya pada satu } \\
\text { sisi }\end{array}$ & $\begin{array}{l}\text { Tersedia, hanya pada satu } \\
\text { sisi }\end{array}$ & $\begin{array}{l}\text { Tersedia, hanya pada satu } \\
\text { sisi. }\end{array}$ & Tersedia & $\begin{array}{l}\text { Tersedia, hanya pada satu } \\
\text { sisi. }\end{array}$ \\
\hline 4 & Tersedia, belum merata. & Tersedia, sudah merata. & Tersedia, sudah merata. & Tidak tersedia & $\begin{array}{l}\text { Tersedia, hanya pada satu } \\
\text { sisi. }\end{array}$ \\
\hline 5 & Tersedia, belum merata & Tersedia, sudah merata. & Tersedia, sudah merata. & Tersedia & $\begin{array}{l}\text { Tersedia, hanya pada satu } \\
\text { sisi. }\end{array}$ \\
\hline 6 & Tidak tersedia & Tidak tersedia & Tersedia, sudah merata. & Tidak tersedia & Tersedia \\
\hline 7 & $\begin{array}{l}\text { Tersedia, berupa pohon } \\
\text { rindang. }\end{array}$ & Tersedia, sudah merata. & Tersedia, sudah merata. & Tidak tersedia & Tidak tersedia \\
\hline 8 & Tidak tersedia & Belum merata. & Tersedia, sudah merata. & Tidak tersedia & Tidak tersedia \\
\hline
\end{tabular}



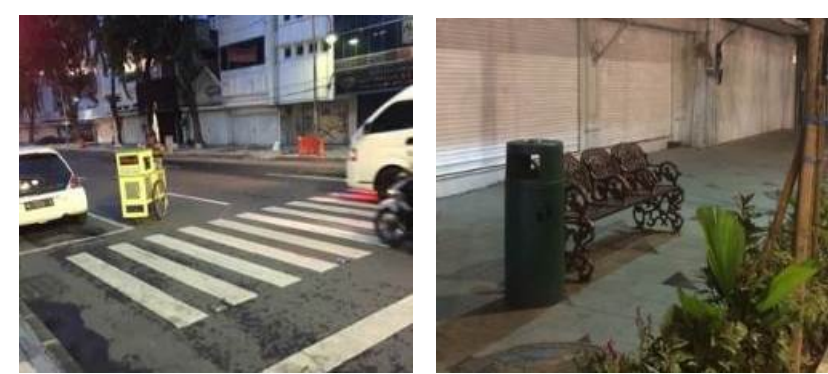

Gambar 7. Fasilitas jalur pejalan kaki

Berdasarkan tabel hasil observasi di atas, dapat diketahui bahwa kondisi jalur pejalan kaki masih belum sepenuhnya baik karena masih terdapat beberapa komponen jalur pejalan kaki yang masih belum terpenuhi. Kondisi jalur pejalan kaki yang baik dapat mendukung penggunaan jalan sebagai ruang publik.

\section{KESIMPULAN/RINGKASAN}

1. Jenis penggunaan lahan yang mendominasi di koridor Jalan Tunjungan adalah perkantoran dan perdagangan jasa.

2. Masih terdapat banyak bangunan kosong yang tidak memiliki kegiatan di Jalan Tunjungan.

3. Bentuk bangunan didominasi oleh bangunan dengan frontage tidak aktif.

4. Frontage bangunan yang tidak aktif dapat diklasifikasikan menjadi bangunan dengan dinding pembatas, bangunan kosong, bangunan dengan dinding impermeable, dan bangunan dengan setback.

5. Jalur pejalan kaki sudah tersedia secara merata di koridor Jalan Tunjungan.

6. Lebar jalur pejalan kaki masih belum seragam dan beberapa masih belum memenuhi standar.

7. Penyediaan fasilitas jalur pejalan kaki sudah baik namun masih perlu peningkatan.

\section{DAFTAR PUSTAKA}

[1] R. Krier, Urban space (Stadtraum). London: Academy Editions, 1979.

[2] J. Jacobs, The death and life of great American cities. New York: Random House, 1961.

[3] B. Appleyard, AICP, and L. Cox, “At Home in The Zone : Creating livable streets in the U.S,” Planning, pp. 30-35, Oct-2006.

[4] M. Rodiyani, "Analisis dampak lalu lintas akibat adanya Tunjungan City,” Institut Teknologi Sepuluh Nopember, 2012.

[5] D. Appleyard, M. S. Gerson, and M. Lintell, Livable streets. Berkeley: University of California Press, 1981.

[6] R. K. Untermann and L. Lewicki, Accommodating the pedestrian : adapting towns and neighborhoods for walking and bicycling. New York : Van Nostrand Reinhold, 1984.

[7] D. B. Oswan and L. S. Arifin, "Fungsi pedestrian jalan Tunjungan dari sirkulasi ke rekreasi: studi kasus berdasarkan kesejarahan," Dimens. (Journal Archit. Built Environ., vol. 40, no. 2, pp. 99-112, Dec. 2013.

[8] R. Trancik, Finding lost space : theories of urban design. New York: Van Nostrand Reinhold, 1986.

[9] M. Francis, L. G. Rivlin, A. M. Stone, and S. Carr, Public space. New York: Cambridge University Press, 1992. 